\title{
Dwindling Graduate Student Enrollments in Distance-Based Programs: A Researched-Based Exploration with Underlying Findings and Premise
}

\author{
Dr. Mitchell L. Springer PMP, SPHR, SHRM-SCP, Purdue University, West Lafayette (College of Engineering)
}

Dr. Mitchell L. Springer PMP, SPHR, SHRM-SCP

Dr. Springer currently serves as an Executive Director for Purdue University's Polytechnic Institute located in West Lafayette, Indiana. He has over 35 years of theoretical and Defense industry-based practical experience from four disciplines: Software Engineering, Systems Engineering, Program Management and Human Resources. Dr. Springer possesses a significant strength in pattern recognition, analyzing and improving organizational systems. He is internationally recognized, has contributed to scholarship more than 200 books, articles, presentations, editorials and reviews on software development methodologies, management, organizational change, and program management. Dr. Springer sits on many university and community boards and advisory committees. He is the recipient of numerous awards and recognitions, most recently, the Purdue University, College of Technology, Equity, Inclusion and Advocacy Award. Dr. Springer is the President of the Indiana Council for Continuing Education as well as the Past-Chair of the Continuing Professional Development Division of the American Society for Engineering Education.

Dr. Springer received his Bachelor of Science in Computer Science from Purdue University, his MBA and Doctorate in Adult and Community Education with a Cognate in Executive Development from Ball State University. He is certified as a Project Management Professional (PMP), Senior Professional in Human Resources (SPHR \& SHRM-SCP), in Alternate Dispute Resolution (ADR), and, in civil and domestic mediation. Dr. Springer is a State of Indiana Registered domestic mediator.

\section{Mr. Mark T. Schuver, Purdue University, West Lafayette (College of Engineering)}

Mark Schuver is the Director for the Center for Professional Studies in Technology and Applied Research (ProSTAR) in the Polytechnic Institute at Purdue University in West Lafayette, Indiana. He is responsible for the administration/operations of the Center with Program Management oversight of the Rolls-Royce Master of Science Degree, the Construction Management Master of Science Degree and Product Lifecycle Management Certificate Programs for working professionals. Prior to joining Purdue in 2002, Mark was employed by Caterpillar, Inc for 35 years with assignments in Product Design, Research and Development, Supplier Management, Quality Management, Logistics Management and various leadership positions. He holds an Associate Degree in Drafting Technology from North Iowa Area Community College, a BS in Business Administration and MS in Management from Indiana Wesleyan University.

Mark is a member of the American Society for Engineering Education and serves on the Executive Board of the Continuing Professional Development Division. He is also a member of College/Industry Partnerships, Engineering Technology and Graduate Studies Divisions of ASEE. Mark is a Lifetime Certified Purchasing Manager with the Institute of Supply Management (formerly NAPM). 


\title{
Dwindling Graduate Student Enrollments in Distance- Based Programs: A Researched-Based Exploration with Underlying Findings and Premise
}

\begin{abstract}
At the American Society for Engineering Education (ASEE), Conference for Industry \& Education Collaboration (CIEC) 2017 in Jacksonville, Florida, the Special Interest Group on Administration (SIG-Admin) focused on individual college/university experiences of dwindling enrollments in graduate distance programs.

Based on recent research, this paper focuses on the quantitative realities of this perception and the numerous multi-faceted complexities contributing to the underlying premise of the suggestion. The paper reviews the numerical basis for this concern, as well as looks at the many peripheral and cumulative factors contributing to the concern. This paper focuses on the current trends in declining on-campus enrollments and the offset increase in distance-based enrollments.

From the perspective of declining tuition-based on-campus higher education enrollments, this paper will share insights into contributing population demographics, the rationale behind declining numbers of high school graduates, student preferences for staying close to home, and, the challenges of current and future learners.
\end{abstract}

From the perspective of increasing distance-based enrollments, this paper will focus on the contributing factors of distance trend enrollments nationally and by region, by type of institution; public, private non-profit and private for-profit, and by sector of institution. The paper also draws from longitudinal data of the top 50 distance providers.

Overall, this paper focuses on the many perceived separate, yet highly related, contributing factors to higher education enrollments, both on-campus and at a distance. While it is recognized these may not be representative of the entirety of those factors contributing to perceived distance dwindling enrollments, the contributing data that follows certainly appears, inductively, to be part of the underlying basis of the discussion.

\section{Introduction}

While attending the Conference for Industry \& Education Collaboration (CIEC) in 2017 at Jacksonville, Florida, a Special Interest Group (SIG) on administration pondered the greatest challenges and concerns for those many individuals and their universities/colleges participating. Although there were many topics discussed, the one recurring topic of greatest interest, the one keeping most awake at night, was the topic of university specific dwindling enrollments in professional graduate programs. 
The first instinct of the group was to question program offerings and/or program quality. If program offerings and/or quality had been applicable to a larger number of the many represented colleges/universities, then perhaps this aspect of concern may have been more widely accepted and subject to further investigation. However, this was not the case. As discussion carried on into the late evening, it became more obvious the factors contributing to the perception of dwindling enrollments was much more complex and multi-faceted, beyond simply program offerings and/or program quality; although these could certainly be contributing factors.

This paper focuses on the many perceived separate, yet highly related, contributing factors to the perception of dwindling professional program enrollments. While it is recognized these may not be representative of the entirety of those factors contributing to dwindling enrollments [16], the discussion that follows certainly appears, inductively, to be part of the underlying basis of the discussion.

\section{Literature Review}

At this writing, higher education on-campus tuition-based enrollments are down, while at the same time, distance-based offerings, that being all mediums of distance delivery, are up and increasing.

Multiple factors, two of which discussed herein, contribute to tuition-based on-campus declining enrollments.

a Population demographics - which are increasing at a decreasing rate.

- The dwindling number of high school graduates - which, from the research, is premised on declining birth rates, contributed to by higher levels of educational attainment, career pursuits, and increasing greater graduation debt loads [15].

In reviewing the literature on distance and distance-hybrid based courses/programs, the literature reviewed focuses on:

口 Overall increase/decrease in distance education enrollments.

口 Distance enrollments differing by university type, sector within each type and regions.

\section{Definitions}

Before continuing, it is necessary to initially briefly define the three types of institutions forming a part of this paper. The three types of addressed institutions are public, private non-profit and private for-profit; all as defined below.

- Public Institution - The name that is applied to a school, college, courthouse, library, hospital and other place that is funded, in whole or part, by tax payer dollars for public use. The opposite of a private institution. 
a Private Non-Profit - Nonprofit institutions may receive funding from the government, tuition and endowments, and the money received is put back into the curriculum, instruction and other college operations (Duke, Harvard, Northwestern, Georgetown, Syracuse...)

口 Private For-Profit - Private colleges and universities are funded by endowments, tuition and donations. Interest in creating value for shareholders. A private college can be a forprofit or nonprofit institution.

\section{Higher Education Tuition-Based On-Campus Enrollments are Down}

In the Distance Education Learning Report, Allen and Seaman [1] report higher education enrollments, overall, for academic years spanning 2012-2015, are down across public and private for-profit institutions, while enrollments are slightly higher in private non-profit institutions. Figure 1 below depicts this relationship.

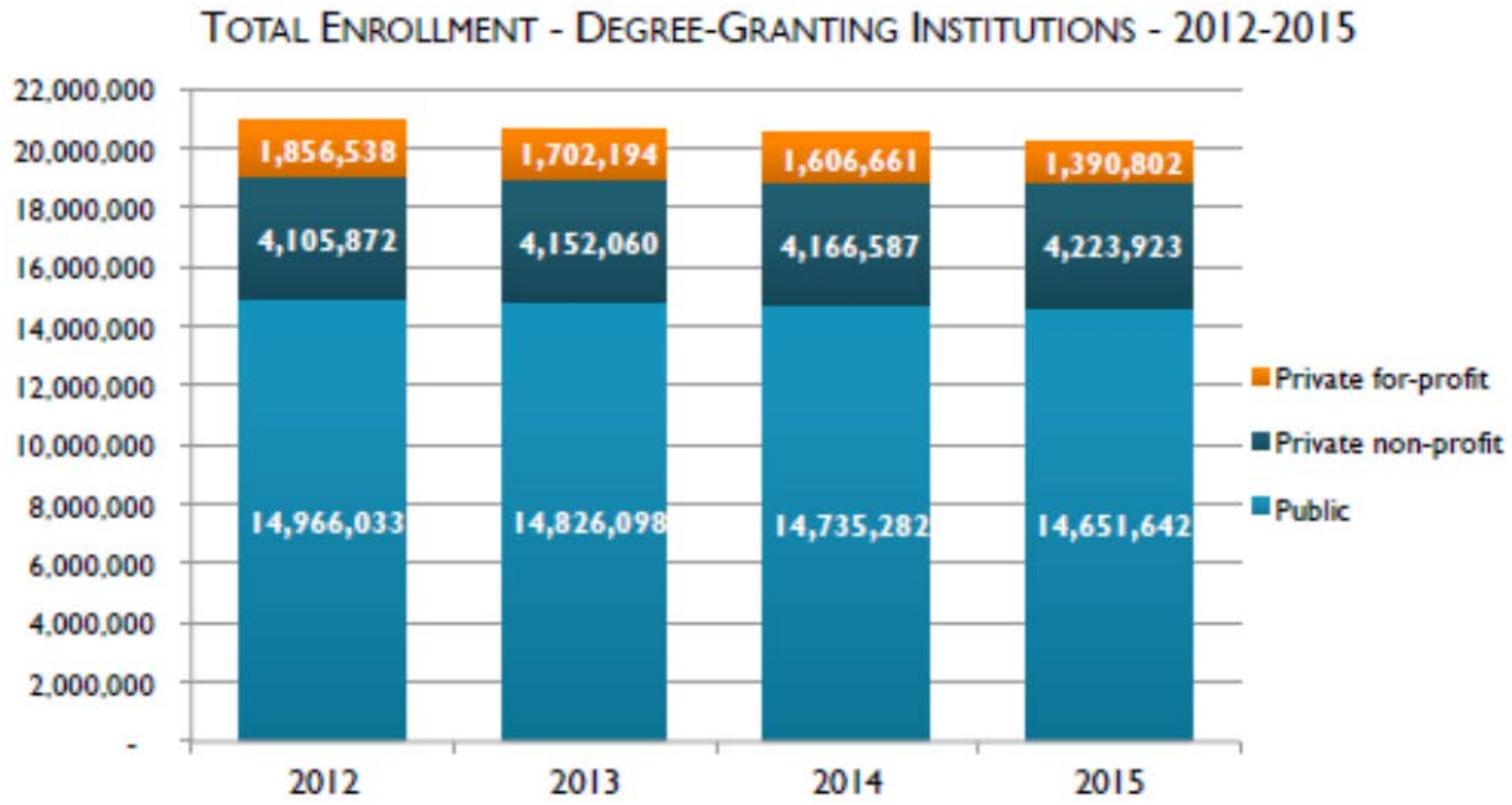

Figure 1 - Enrollments by Type of Institution [1]

The Allen and Seaman data reflects nearly a one million student decrease of -931,317 in students studying on campus. Figure 2 below depicts both the percent change from 2012 - 2015 as well 
as the equivalent student population. Worth noting is that public universities maintain the predominance of total student enrollments, both as a headcount and as a percentage.

NUMBER OF STUDENTS STUDYING ON CAMPUS - 2012-2015

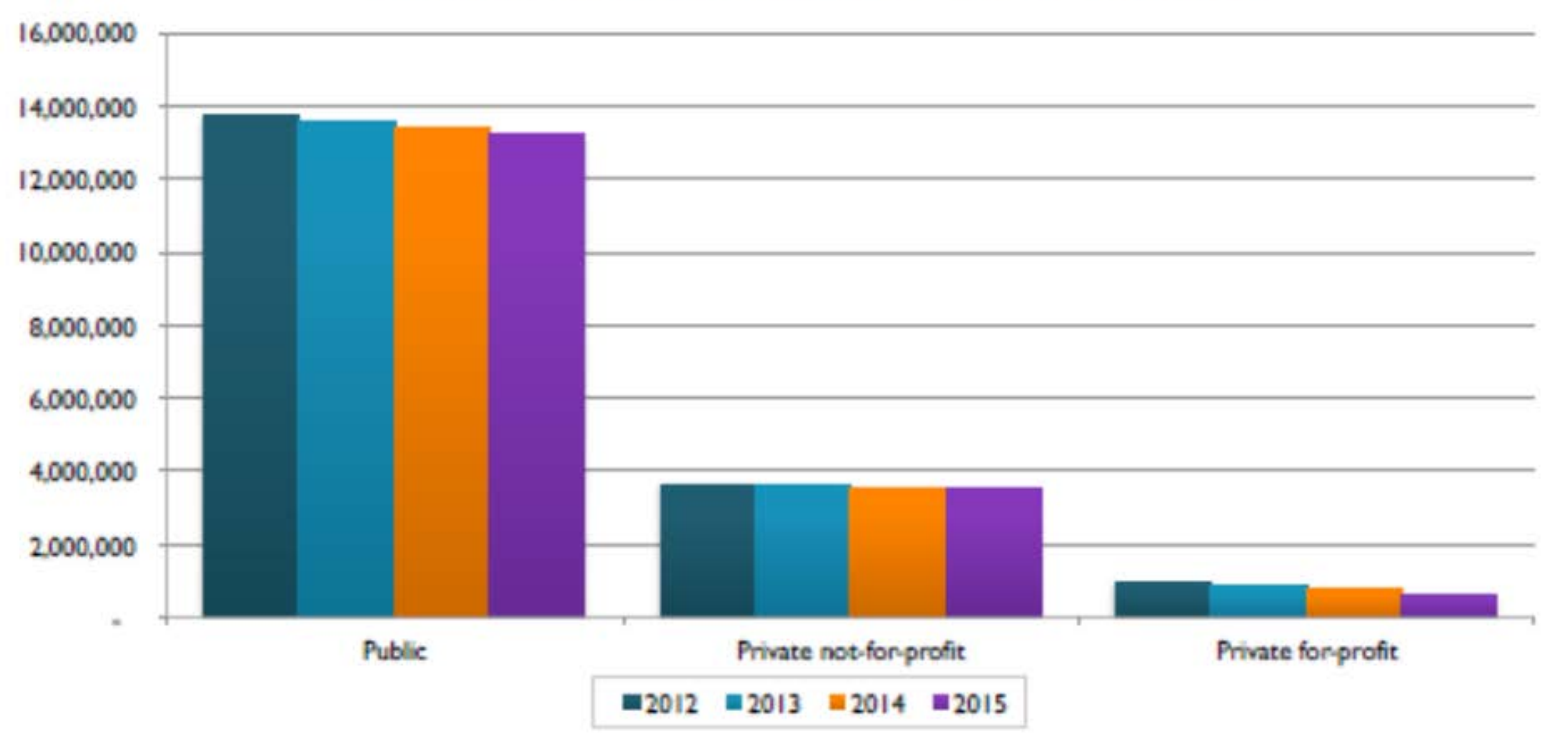

Change in Number of On Campus Students - 2012 to 2015

\begin{tabular}{|lcr|} 
& Change 2012 to & Percent Change \\
Control of institution & 2015 & 2012 to 20I5 \\
\hline Public & $(539.271)$ & $-3.93 \%$ \\
\hline Private non-profit & $(100.863)$ & $-2.78 \%$ \\
\hline Private for-profit & $(291.183)$ & $-31.36 \%$ \\
\hline Total & $(931.317)$ & $-5.09 \%$ \\
\hline
\end{tabular}

Figure 2 - Number and Percent of Student Decline from 2012-2015 [1]

Looking at the data presented by the authors, one would be naturally compelled to ask "where did nearly one million students go?”

Figure 3 below depicts the total student and percent change broken out by sector of institution. 


\section{On Campus Students - 2012 to 2015}

\begin{tabular}{|lrr|}
\hline Sector of institution & $\begin{array}{c}\text { Change 2012 } \\
\text { to 2015 }\end{array}$ & $\begin{array}{c}\text { Percent } \\
\text { Change 2012 } \\
\text { to 2015 }\end{array}$ \\
\hline Public, 4-year or above & 101.445 & $1.3 \%$ \\
\hline Private non-profit, 4-year or above & $(113.063)$ & $-3.1 \%$ \\
\hline Private for-profit, 4-year or above & $(181.680)$ & $-31.4 \%$ \\
\hline Public, 2-year & $(640.716)$ & $-10.4 \%$ \\
\hline Private non-profit, 2-year & 12.200 & $32.2 \%$ \\
\hline Private for-profit, 2-year & $(109.503)$ & $-31.4 \%$ \\
\hline Total & $(931.317)$ & $-5.1 \%$ \\
\hline
\end{tabular}

Figure 3 - Student enrollment Decline by Institution Sector [1]

From figure 3, the students did not migrate to those institutions with a negative percent change from 2012-2015; namely, they did not go private non-profit 4-year or above, private for-profit 4year or above, public 2-year, or, private for-profit 2-year. It appears the sole significant increase in enrollment institution type was to private non-profit 2-year institutions.

On reflection, if total loses do not add up to equal total gains, then where did the students go? Further research suggests there are simply not as many students; but why?

The following research discusses why there are fewer student enrollments based on demographic changes.

\section{Population Demographics - Increasing at a Decreasing Rate}

Since 1996, every 8.5 seconds someone turned age 50. Since January 2006, someone turned 60 years of age, and since January 1, 2011, every 8.5 seconds someone turned 65 at a rate of nearly 10,000 per day, approximately 4 million per year, until 2029.

Contributing to the reduction of the available workforce, by age 62, 50 percent of both science and engineering bachelor's and master's degree holders will no longer work full time; however, science and engineering doctorate holders do not reach the 50 percent mark until age 66. According to the Science and Engineering Indicators, by age 65, more than half of the science and engineering bachelor's and master's degree holders will leave the workforce entirely, but a similar proportion of Ph.D. holders do not do so until age 68 [2]. Overall, ignoring education level, Americans are choosing not to wait to reach 65 to retire, $60 \%$ of workers currently retire at age 62, a pattern that shows little sign of changing [3]. More specifically, working individuals 
with Bachelor's degrees will generally not work full time by age 62; Master's degree holders by age 62, and Doctorate degree holders by age 66. Which means, from January 1, 2008, the age Boomers first started to turn 62, and then January 1, 2011, the age Boomers first started to turn age 65, we would expect to experience a significant exiting of skilled labor. This clearly represents a trough in the available workforce when compared to the available backfill of Gen $\mathrm{X}$ 'ers.

Restating, since January 1, 2011, someone turned 65 years of age at a rate of nearly 10,000 per day, approximately 4 million per year, until 2029. This is not necessarily good or bad, it simply provides interesting information for thought and planning in everything from produced goods to services.

Current revisions to the mortality tables used by insurance companies reflect a reduced risk of dying at all ages. The average life expectancy is currently 78 for males and 82 for females [4]. Under the old mortality tables, the ultimate life expectancy was just over 99 years. Now, that figure has been lengthened to 120.5 years [5].

Data from the National Science Foundation (NSF) and the United States Bureau of Census clearly reflects an aging world population coupled with a substantial existing decrease in U.S. population after 1960. From 1900 to 2000, the U.S. population increased three times, while the number of individuals 65 and older increased eleven times. Within the U.S. population, 1 in 8 people were aged 65 and above in 2005, 1 in 6 by 2020; 1 in 5 by 2030; in the year 2100 the number of individuals 65 and above will be greater than the entire U.S. pop in 1940 of 131.2 million. This general aging of the population sheds light on the Social Security issue, fewer people to support those that require Social Security benefits. Women, it could be argued, are the secret heroines of Social Security. If they had not joined the labor force in droves, the financial condition of the Social Security system would be significantly worse than it is today [6].

For every person 65 and older, there were 12 people aged 15 to 64 in 1950. By the year 2045, for every person 65 and older, there will be 4 people aged 15 to 64 to support them. In comparing the years 2000 to 2030, we see an increase in the dependency ratio $21.1 \%$ to $37.0 \%$ of people 65 to those aged 20 to 64 [7].

According to Saunders, “...A closer look at the 2004-14 labor force shows that certain demographic groups are projected to grow more rapidly than others. The labor force will continue to age, with a projected 4.1 percent annual growth of the 55 and older age group, more than four times the rate of growth of the overall labor force. Baby boomers entered the labor market beginning in the late 1960s as a huge wave of workers who swelled the level and growth of the labor force. During the decade of the 1990s, baby boomers were in the prime-age working group of 25- to 54-year-olds, still contributing to a relatively high annual growth of the workforce. They will be concentrated in the 50- to 68-year-old workforce in 2014. The annual growth rate, therefore, between 1984 to 1994 is .4\%; 1994 - 2004, 4.0\%, and, 2004 - 2014, 
4.1\%. Because older workers tend to have significantly lower participation rates, the baby boomer exit from the workforce, as with their entrance, will have significant impacts on the growth of the labor force [8].”

\begin{tabular}{|c|c|c|c|c|c|c|c|c|c|c|c|}
\hline \multirow{3}{*}{$\begin{array}{c}\text { [Numbers in thousands] } \\
\text { Group }\end{array}$} & & & & & & & & & & & \\
\hline & \multicolumn{4}{|c|}{ Level } & \multicolumn{4}{|c|}{ Percent distribution } & \multicolumn{3}{|c|}{ Annual growth rate (percent) } \\
\hline & 1984 & 1994 & 2004 & 2014 & 1984 & 1994 & 1004 & 2014 & $1984-94$ & 1994-2004 & $2004-14$ \\
\hline Total, 16 years and older & 113,544 & 131,056 & 147,401 & 162,100 & 100.0 & 100.0 & 100.0 & 100.0 & 1.4 & 1.2 & 1.0 \\
\hline $16-24$ & 23,989 & 21,612 & 22,268 & 22,158 & 21.1 & 16.5 & 16.5 & 13.7 & -1.0 & 3 & .0 \\
\hline $25-54$ & 74,661 & 93,898 & 102,122 & 105,627 & 65.8 & 71.6 & 71.6 & 65.2 & 2.3 & .8 & 3 \\
\hline 55 and older & 14,894 & 15,547 & 23,011 & 34,316 & 13.1 & 11.9 & 11.9 & 21.2 & .4 & 4.0 & 4.1 \\
\hline \multicolumn{12}{|c|}{ Note: Age of baby boomers is 20-38 in 1984, 30-48 in 1994,40-58 in 2004, and 50-68 in 2014.} \\
\hline
\end{tabular}

Figure 4 - Predominance of Growth in 55+ Age Group [8]

We are not alone, every major developed or undeveloped nation, from Germany, to China, to Japan, to Russia and Brazil are experiencing this phenomenon. We are all seeing a major aging of our world populations [9].

The general aging and subsequent loss of skilled workforce labor coupled with the impending trough, leads to the very natural forecast of a shortfall of skilled U.S. labor in the immediate years.

In the year 2014, it was forecasted there would be roughly 8 million more jobs than people to fill them. By 2020, there is forecasted to be a 21 million person shortfall, where 14 million of those are skilled labor [10]. Interestingly enough, however, in 2014, there were 14 million people available to work between the years of 65 and 74 years of age.

Below depicts other popular forecasts of a skilled labor shortage.

a 2000, it was forecasted we would have a shortfall of skilled labor by 2010; roughly 14 million people, 7 million of which were skilled labor

口 2003, forecasted a shortage of over 10 Million by 2010

口 2006, a shortfall of 6 million skilled people

2010, 4 million, another 8.9 million

2014, 8 million; 14M 65-74 yr olds

口 2015, 300 million new jobs required throughout the world...

口 2020, 55 million job openings in U.S.

ㄱ 2030, 35 million (U.S.); 45 million (Europe)

Figure 5 below depicts the educational attainment supposedly required for the projected 55 million job openings in the U.S in 2020. 


\section{Of the 55 million job openings between 2010 and 2020:}

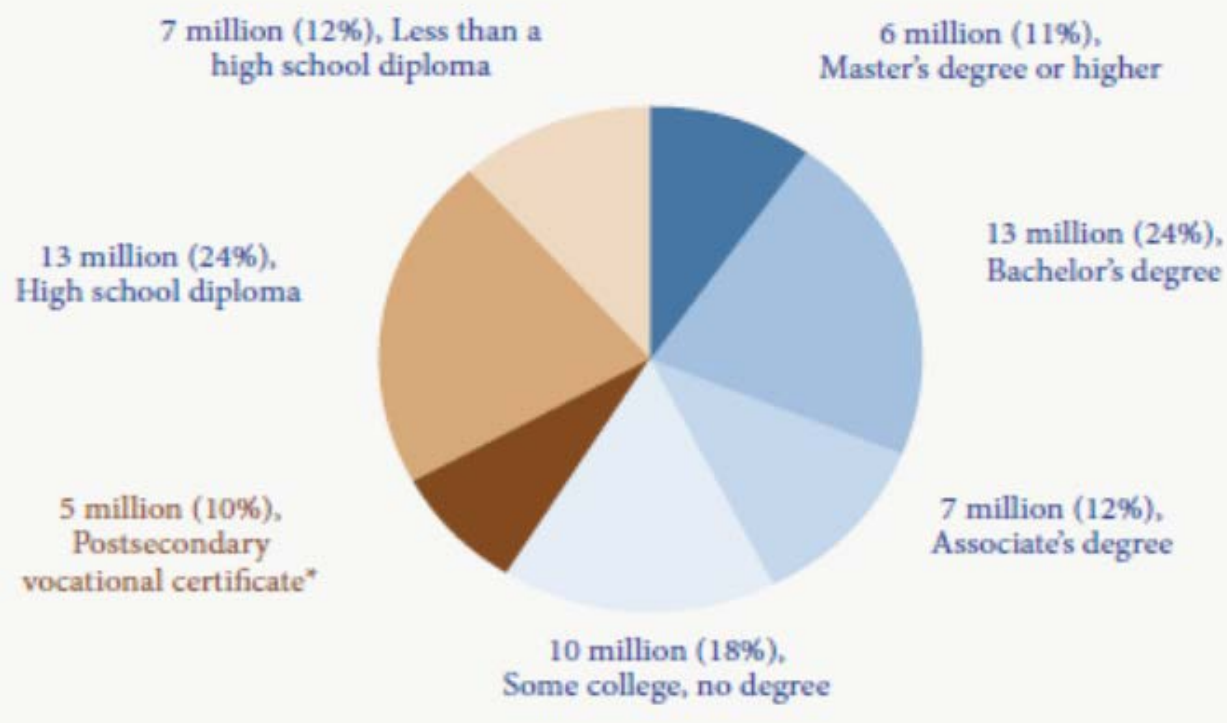

\footnotetext{
"Postsecondary vocational certificate holders are often included in the "some college" category and sometimes in the high school diploma category. For this reason, the numbers in the pie chart above total 61 million job openings due to double-counting. Nevertheless, we estimate the number of postsecondary certificates demanded separately. The number of job openings, however, will be 55 million in the economy through 2020.
}

Figure 5 - Required Educational Attainment of 55 Million Job Openings in 2020 [17]

The reasoning for the projected shortfall of skilled labor is premised on two things: (1) an aging Baby Boomer population, and (2) declining birth rates.

In 1950, the median age in the U.S. was 30 years of age. In 2000, the median age had increased to 35 years of age. By 2050, the median age in the U.S. will be 40. As people age, they consume less in terms of material possessions. Those chronologically aged also reduce their earnings and subsequently their taxes, therefore reducing the overall U.S. tax base.

Complimenting this line of thinking, is the required number of working adults 16-64 who pay into Social Security in support of those who draw down from this Government sponsored social support program. The below table reflects the severity of this ratio from 1940 (the first year social security checks were issued) to more recent 2010. 
"The Social Security Administration predicts that by 2034, the ratio of workersto-retirees will fall to just 2.1 workers for every retiree as a result of (1) roughly 809 million Baby Boomers retiring and (2) the declining fertility rates having failed to produce a proportionate number of new workers [11, pg. 108]."

\begin{tabular}{|l|l|l|l|}
\hline Ration of Workers Paying FICA Taxes to Retirees Collecting Social Security Benefits \\
\hline Year & Workers (in millions) & $\begin{array}{l}\text { Beneficiaries (in } \\
\text { millions) }\end{array}$ & $\begin{array}{l}\text { Ratio (number of } \\
\text { workers supporting } \\
\text { each retiree) }\end{array}$ \\
\hline 1940 & 35.390 & 0.222 & 159.4 \\
\hline 1950 & 48.2850 & 2.930 & 16.5 \\
\hline 1960 & 72.530 & 14.262 & 5.1 \\
\hline 1970 & 93.090 & 25.186 & 3.7 \\
\hline 1980 & 113.656 & 35.118 & 3.2 \\
\hline 1990 & 133.672 & 39.470 & 3.4 \\
\hline 2000 & 155.295 & 45.166 & 3.4 \\
\hline 2010 & 156.725 & 53.398 & 2.9 \\
\hline Source: Social Security $a d m i n i s t r a t i o n$ (http://www.ssa.gov/history/ratios.html). \\
\hline
\end{tabular}

Figure 6 - Number of Workers Supporting Each Retiree

\section{Bench Strength - The Pipeline}

The available number of new births, which feed the high school pipeline of students, is premised on a reduction in the U.S. fertility rate. Factors contributing to the reduced fertility rate are depicted and discussed below.

a Total overall reduction in fertility rate

口 Educational attainment

口 Income attainment

๑ Chronological aging and reduced probabilities of fertility

\section{Declining Fertility Rate}

The total fertility rate is premised on the number of babies the average woman would bear over the course of her life if she were to survive until the end of her reproductive years and agespecific birth rate were to remain constant [12]. 
“...Demographers measure fertility in different ways. They start with the simplest observation: the number of births each year plotted against the numbers and ages of the rest of the population. From there they calculate the "crude birth rate," which is the number of children born per 1,000 people in that particular year. The crude birth rate isn't particularly useful, but for sake of context, the U.S. population was about 312 million in 2011 and about 4 million babies were born, so the U.S. crude birth rate was around 13. By combining the crude birth rate with other census data, you can determine "completed fertility," which is the number of babies actually born to each woman in American by the time she's 50... And finally, there's the "total fertility rate." The TFR is closely related to completed fertility: It's the number of babies the average woman would bear over the course of her life if she were to survive until the end of her reproductive years and age-specific birth rate were to remain constant [12, pg. 5]."

A few quick facts on total fertility rate and its implications on the world population [12, pg. 11].

- The American fertility rate currently sits at 1.93

- In order for a country to maintain a steady population, it needs a fertility rate of 2.1

- Which means that the Japanese and Italians (with fertility rates of about 1.4) are on the verge of downsizing their countries. Their cities are dwindling; some small towns are on the cusp of simply closing

- 1979 world's fertility rate was 6.0 , today it's 2.52

\section{Educational Attainment}

Relative to education and fertility, the more educated a woman becomes, the less children, on average, she has [12, pg. 12].

口 U.S. average 1.93

- College graduate $=1.78$

a Women with a graduate degree $=1.61$ 


\begin{tabular}{|l|l|}
\hline Education level & Total Fertility Rate \\
\hline Not a high school graduate & 2.447 \\
\hline High school, 4 years & 1.947 \\
\hline College, 1 or more year & 1.719 \\
\hline Associate's degree & 1.820 \\
\hline Bachelor's degree & 1.632 \\
\hline Graduate degree & 1.596 \\
\hline $\begin{array}{l}\text { Source: Jane Lawler Dye, U.S. Census Bureau, "Fertility of } \\
\text { American Women: 2006," August 2008. }\end{array}$ \\
\hline
\end{tabular}

Figure 7 - Educational Impact on Fertility [12]

Education, then, is directly correlated with delayed family formation. The drop in fertility among women with college and advanced degrees, then, is in large part a function of delayed family formation.

Specifically, it's not just the length of education that diminishes fertility, or the careers the education makes possible, but the debt load the education incurs. Since 1987, when the Nellie Mae Corporation began keeping statistical track of student loans, the average student- loan burden on college graduates has almost quadrupled, from $\$ 7,500$ to $\$ 37,172$.

\section{Income Attainment}

In looking at income and fertility rates, there is again a direct correlation between increasingly higher levels of income and decreasing fertility rates [12]. As the below chart depicts, household income level under $\$ 20,000.00$ represents the highest fertility rate at 2.038. As household income rises up through the range of roughly $\$ 75,000$ to $\$ 100,000$ per year, fertility rates decline and stabilize around $1.75 \%$. Household incomes over $\$ 100,000$ show a slight uptick from the $1.75 \%$ to $1.83 \%$, but far less than the highest fertility rate of 2.038 . 


\begin{tabular}{|l|l|}
\hline Household Income Level & Total Fertility Rate \\
\hline Under $\$ 20,000$ & 2.038 \\
\hline$\$ 20,000$ to $\$ 29,000$ & 1.988 \\
\hline$\$ 35,000$ to $\$ 49,999$ & 2.052 \\
\hline$\$ 50,000$ to 74,999 & 1.734 \\
\hline$\$ 75,000$ to $\$ 99,000$ & 1.752 \\
\hline$\$ 100,000$ and over & 1.832 \\
\hline $\begin{array}{l}\text { Source: Jane Lawler Dye, U.S. Census Bureau, } \\
\text { "Fertility of American Women: } 2006, \text {," August 2008. }\end{array}$ \\
\hline
\end{tabular}

Figure 8 - Impact of Income on Fertility [12]

\section{Effects of Chronological Aging and Fertility}

Given young adult college graduates are assuming increasingly greater levels of school loan debt, are forced into moving back home for a period of time, delay marriage, opting to find gainful employment and establish their careers all prior to having children; when, then, do these young individuals have their first born child and how does that compare to previous generations?

The answer, as might be expected, is the median age of first time parents has skewed to the right; meaning, the median age of first time parents has gone up. Date reflects the median age for first time parents has increased as much as $5 \%$ for mothers 30 - 35 years and older; this while 20 to 30 year old first time mothers decreased in age by $3 \%$.

In looking at the second figure below, the Center for Disease Control depicts declining birth rates for three age categories, 15-19, 20-24 and 24-29; while depicting increasing birth rates for age groups 30-34, 35-39 and 40-44. 


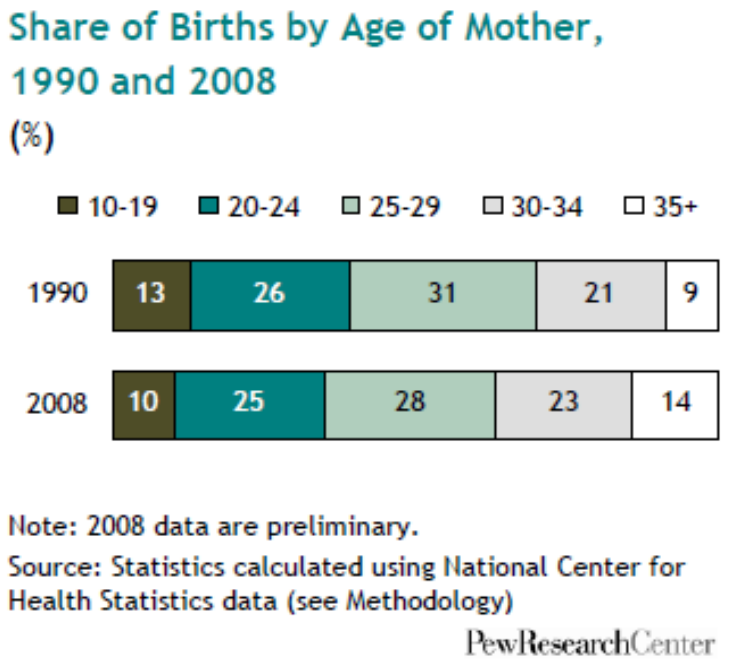

Source: Statistics calculated using National Center for Health Statistics data (see Methodology)

$$
\text { PewResearchCenter }
$$

Figure 9 - Increase in Age of First Births [18]

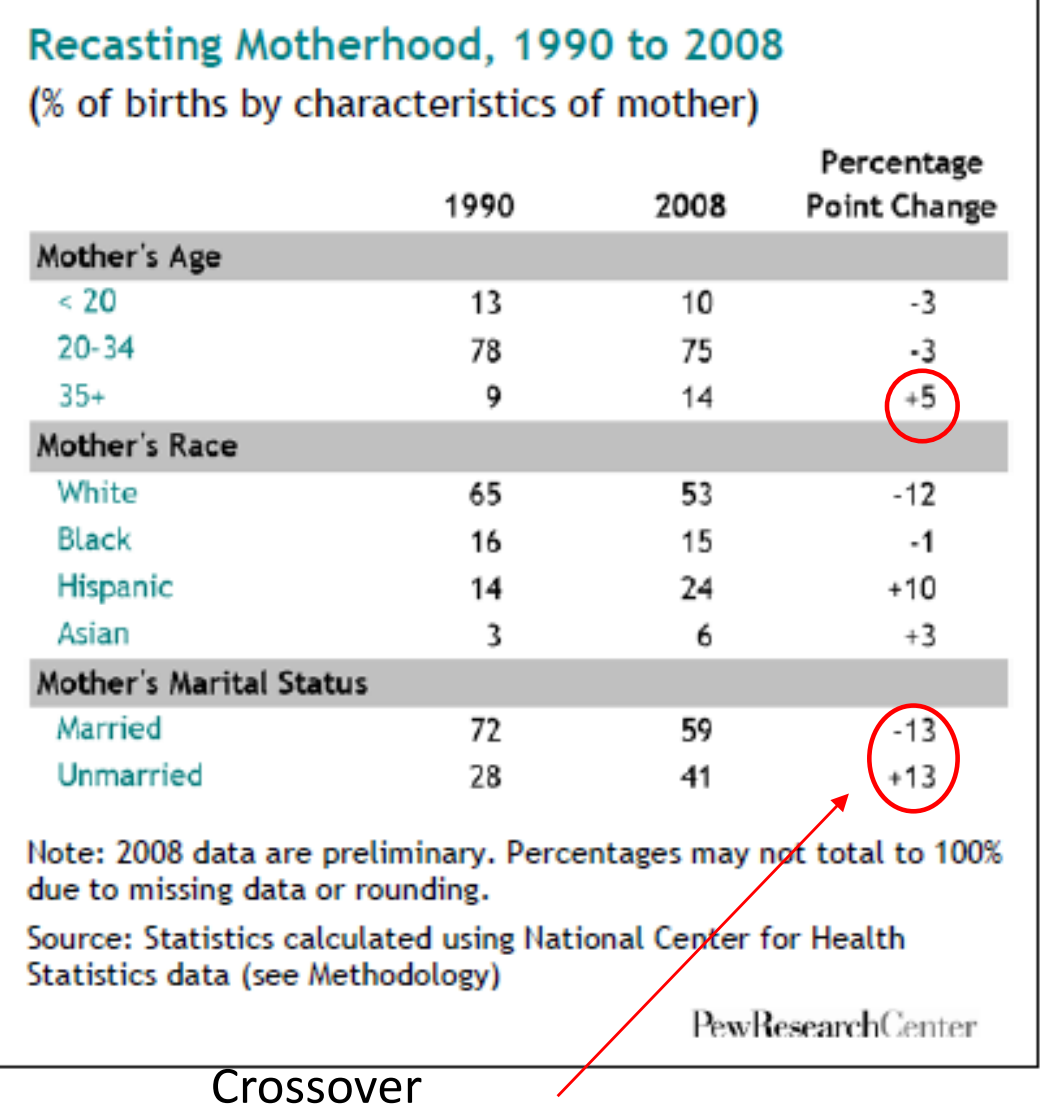

Figure 10 - Increase in Births of Unmarried Mothers [18] 
From another perspective, the skewing of median age of first marriage and children, has its limits. From a biological perspective, between the ages of 24 and 34, a woman's chance of becoming infertile increases from 3 percent to 8 percent. By 35, half of all women trying to get pregnant over the course of 8 months will not succeed. After 35 it gets even more difficult. By age 39, a woman has a 15 percent chance of being unable to conceive at all. And, by a woman's 43 birthday, her chances of getting pregnant are nearly zero. All of which is why today, 1 out of every 100 babies born in the United States is created via in vitro fertilization [12, pg. 51].

\section{Declining Number of High School Students/Graduates - Interpreting the Data}

Given the changing face of the U.S. population demographics and declining birth rates, it can be intuitively stated there is an expected declining number of high school graduates [13]. This portion of the paper will focus on the impact to higher education of this very real reduction, namely:

글 Hewer High School graduates between 2014 - 2023; and again from 2026-2032

口 Private schools - religious and nonsectarian decline at greater rates

G Growth in South \& West regions; declines Northeast \& Midwest regions

In looking at the below figure, it can be seen there is a declining enrollment projection between 2014 and 2023. There is a slight uptick from 2024 through 2025, and a resumed declining enrollment between 2026 through 2032.

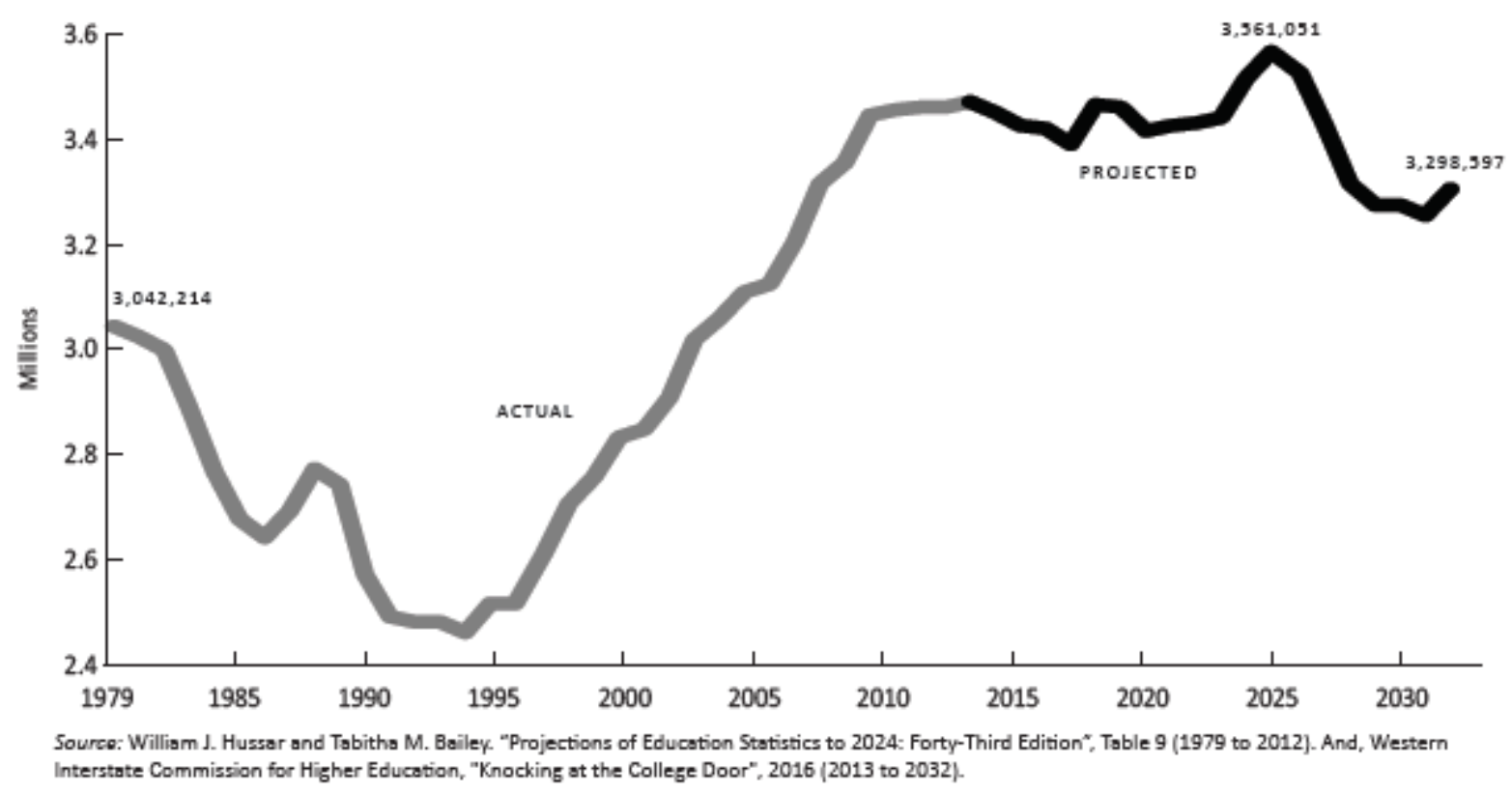


Figure 11 - Enrollment Past and Future Through 2032 [13]

The below figure depicts private religious and nonsectarian enrollments will decline even further.

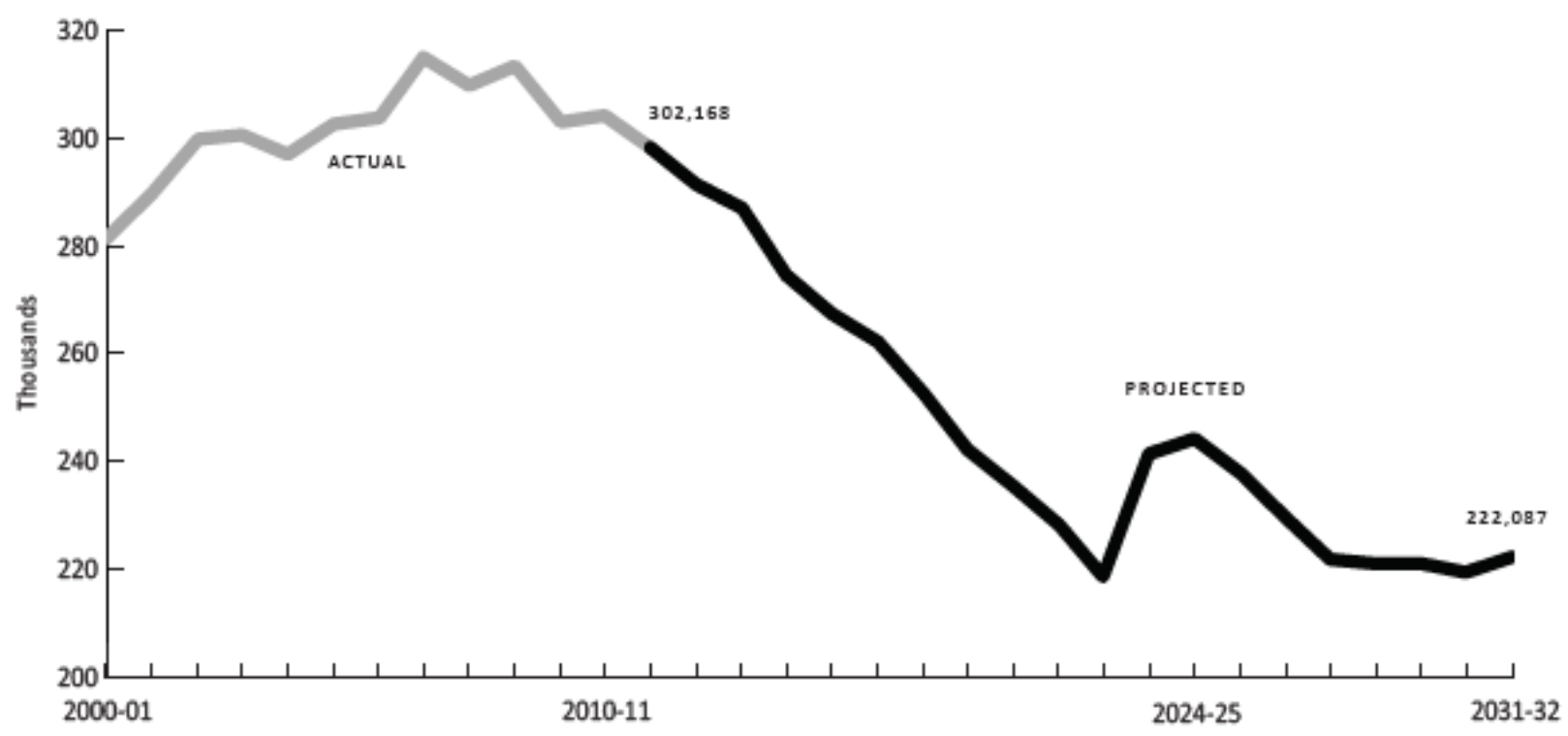

Figure 12 - Private Religious and Nonsectarian Declines [13]

The portions of the U.S. that will experience the greatest, or stated differently, the least impact to graduation enrollments, is the southern portions, reflecting an increase of 7,100. The other three regions of the U.S., West, Midwest and Northeast will all experience declining enrollments of $45,900,-92,700$ and $-72,300$ respectively. The two charts that follow depict this enrollment change by table and chart.

\begin{tabular}{crrr} 
& $2019-20$ & $2024-25$ & $2029-30$ \\
\hline South & 32,200 & 117,900 & 7,100 \\
\hline West & $-11,500$ & 24,900 & $-45,900$ \\
\hline Midwest & $-41,200$ & $-29,700$ & $-92,700$ \\
\hline Northeast & $-42,000$ & $-26,200$ & $-72,300$ \\
\hline
\end{tabular}




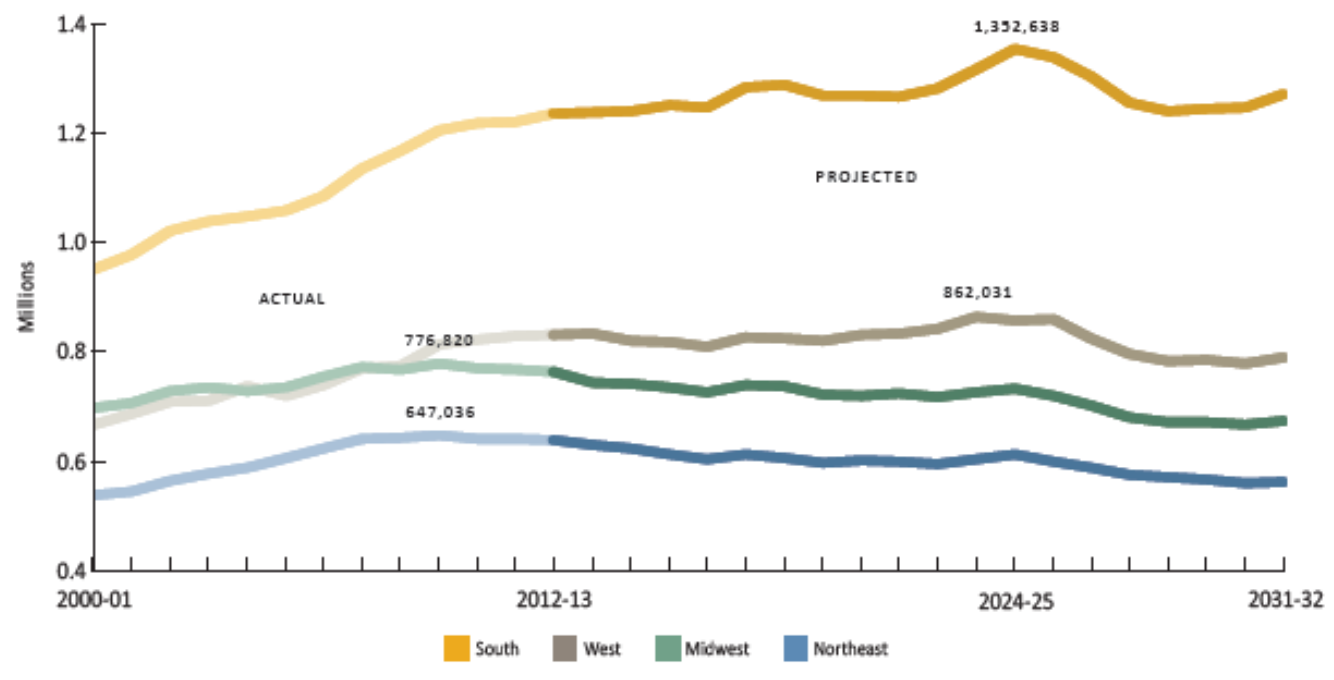

Figure 13 - Declining High School Enrollment Impact by Region [13]

The below chart depicts the changing enrollments from the 2008-2009 academic year as an 11 and 16 year perspective. This chart provides a visual perspective from the breakeven point of zero change. Again, the south region of the U.S. (11 year) and the south and west regions (16 year) clearly depict benefits from changing high school enrollment projections.

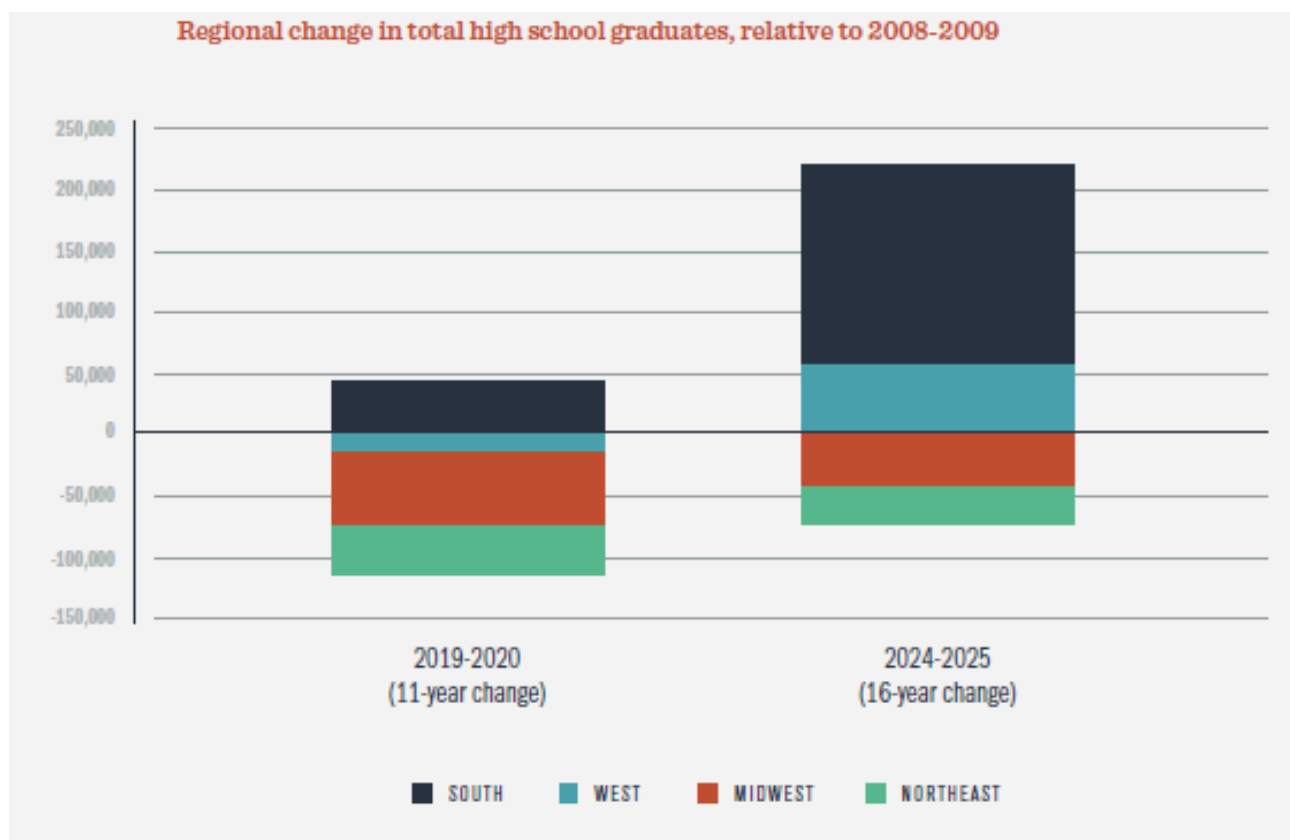

SOURCE: WESTER INTERSTUTE CONWISSION FOR HIGHER EDUCATION

Figure 14 - Break Even Perspective from 2008-2009 Academic Year [13] 


\section{Distance Education Enrollments are Increasing}

The research literature suggests the number of students graduating from high school are dwindling and may be a contributing factor to the dwindling tuition-based on-campus enrollments. This, however, is not the case for distance enrollment in higher education.

Distance-based higher education enrollments are increasing in both categories of students taking exclusive distance courses and some distance courses. In Knocking at the College Door [14], the authors present data to suggest distance courses are being taken in increasing numbers, but not evenly distributed across institutional sector or region.

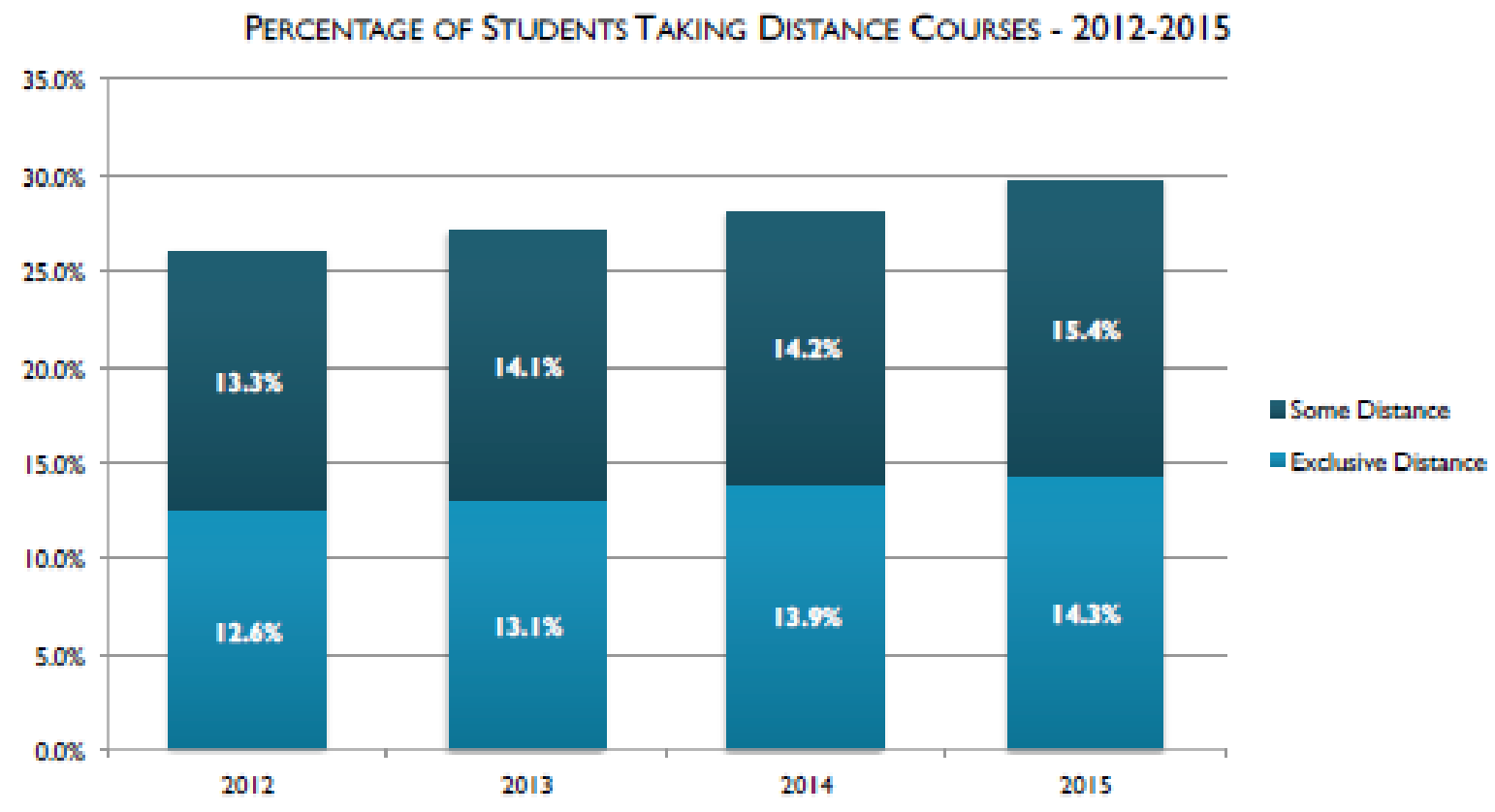

Figure 15 - Increase in Distance Education by Type [14]

Distance education courses are being taken at both the undergraduate and graduate levels as depicted below. 


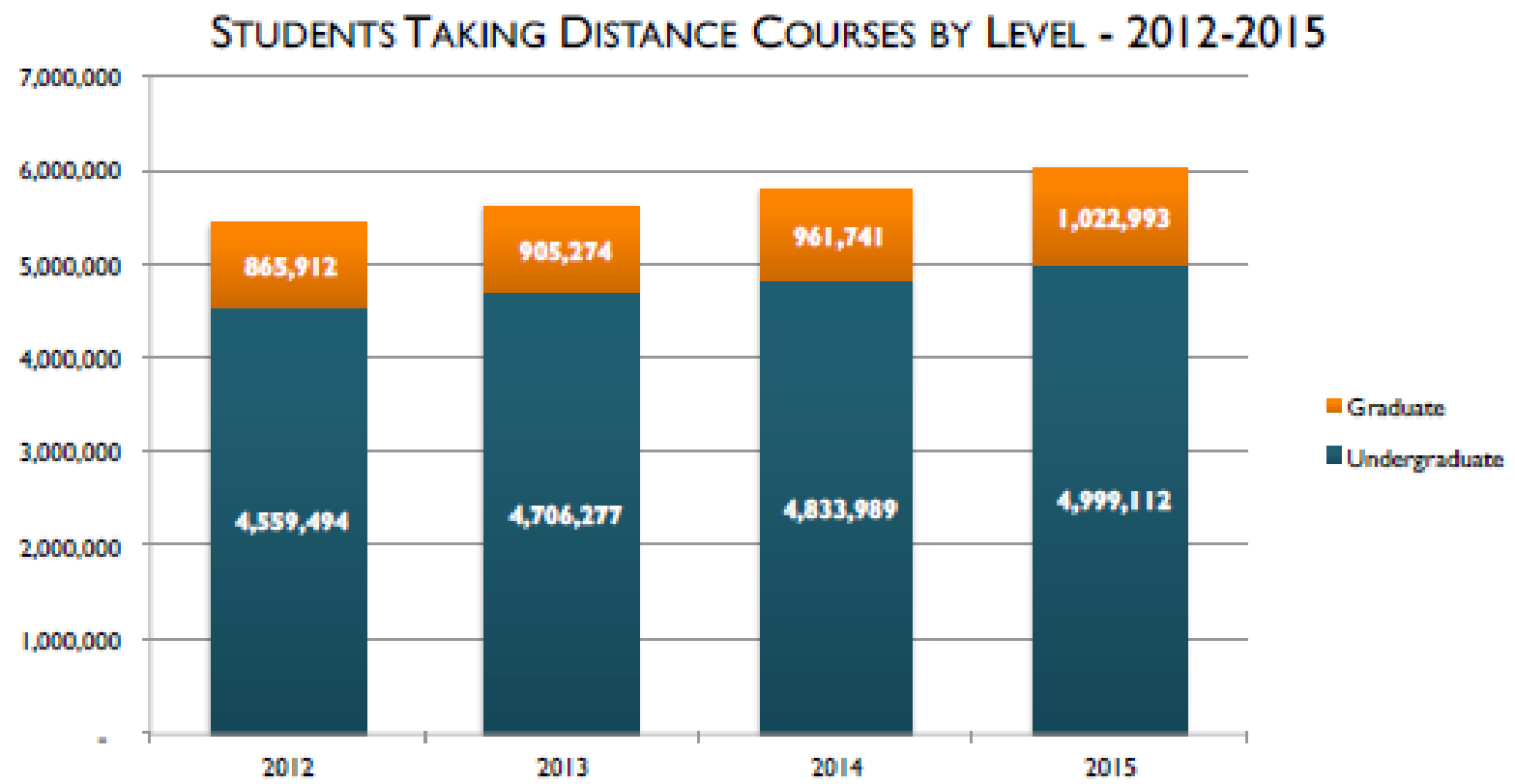

Figure 16 - Distance Enrollments increased at Both the Undergraduate and Graduate Levels [14]

Public institutions of higher education enroll the greatest percentage of distance learners, representing $67.8 \%$, followed by private non-profit at $17.8 \%$ and private for-profit at $14.5 \%$.

TYPE OF INSTITUTION - STUDENTS ENROLLED IN DISTANCE EDUCATION COURSES - 2015

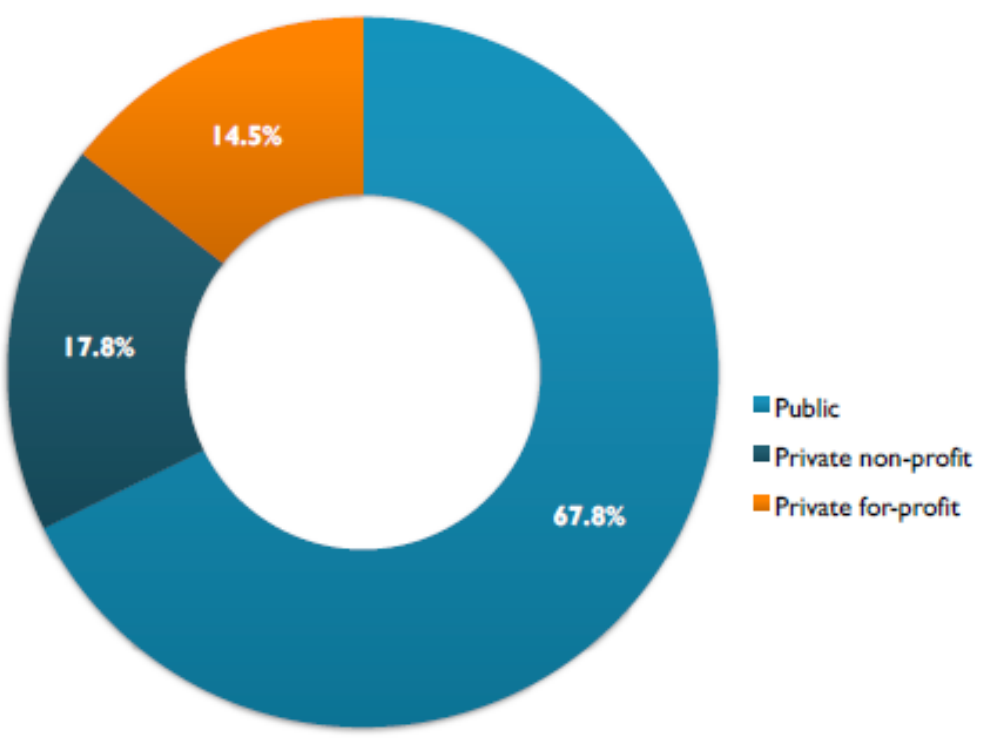

Figure 17 - Distance Education Enrollments by Type of Institution [14] 
Enrollments over the 2012-2013, 2013-2014 and 2014-2015 academic years have been unevenly distributed by institution type. Public institutions have changed over the three-year period from $+161,242$ to $-73,577$, while private non-profit have changed from $+113,154$ to $-27,281$, and, private for-profit with the greatest change of $+207,348$ to $-90,442$.

YeAR-TO-YeAR CHANGE IN DISTANCE ENROLLMENTS - DegreE-

GRANTING INSTITUTIONS - 20I2-20I5

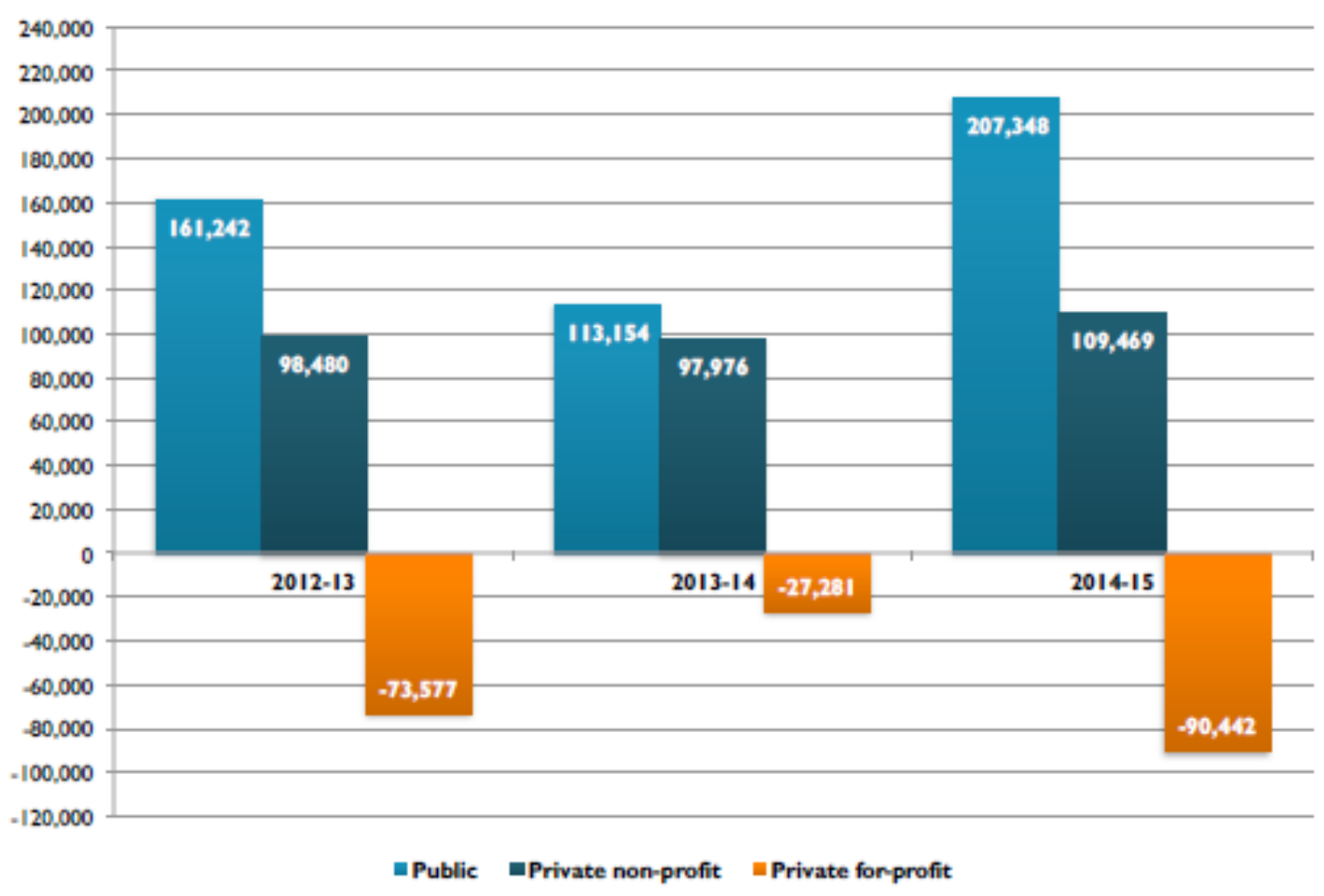

Figure 18 - Enrollments Unevenly Distributed by Institution Type [14]

In terms of percent change, private non-profit lead with a $+40 \%$ change over the same 2012-2015 academic year spread, while public intuitions witnessed a percent change of $+13.4 \%$ and private for-profit institutions experienced a $-18 \%$ change over this same period. 

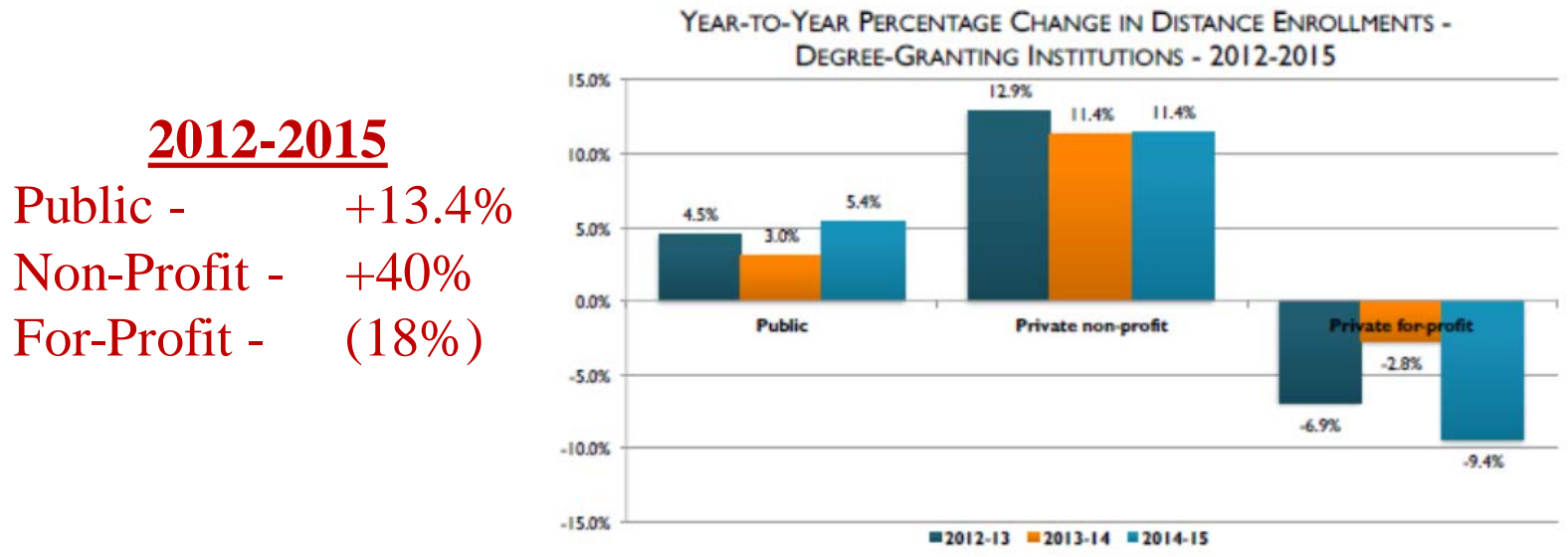

Figure 19 - Distance Enrollments Percent Change 2012-2015 [14]

During this same period 2012-2015, institutional sector made a difference in enrollment experiences. For purposes of this paper, graduate enrollments are of most importance. Graduate distance enrollments showed the greatest enrollment growth in private non-profit, 4-year and above institutions (+33\%), followed by public institutions $(+20.4 \%)$ and private for-profit institutions with the only negative percent change in distance enrollments $(-2.3 \%)$. Overall distance enrollments across all types of institutions is up a significant 18.1\%; while, again, not being evenly allocated by sector or type of institution. 


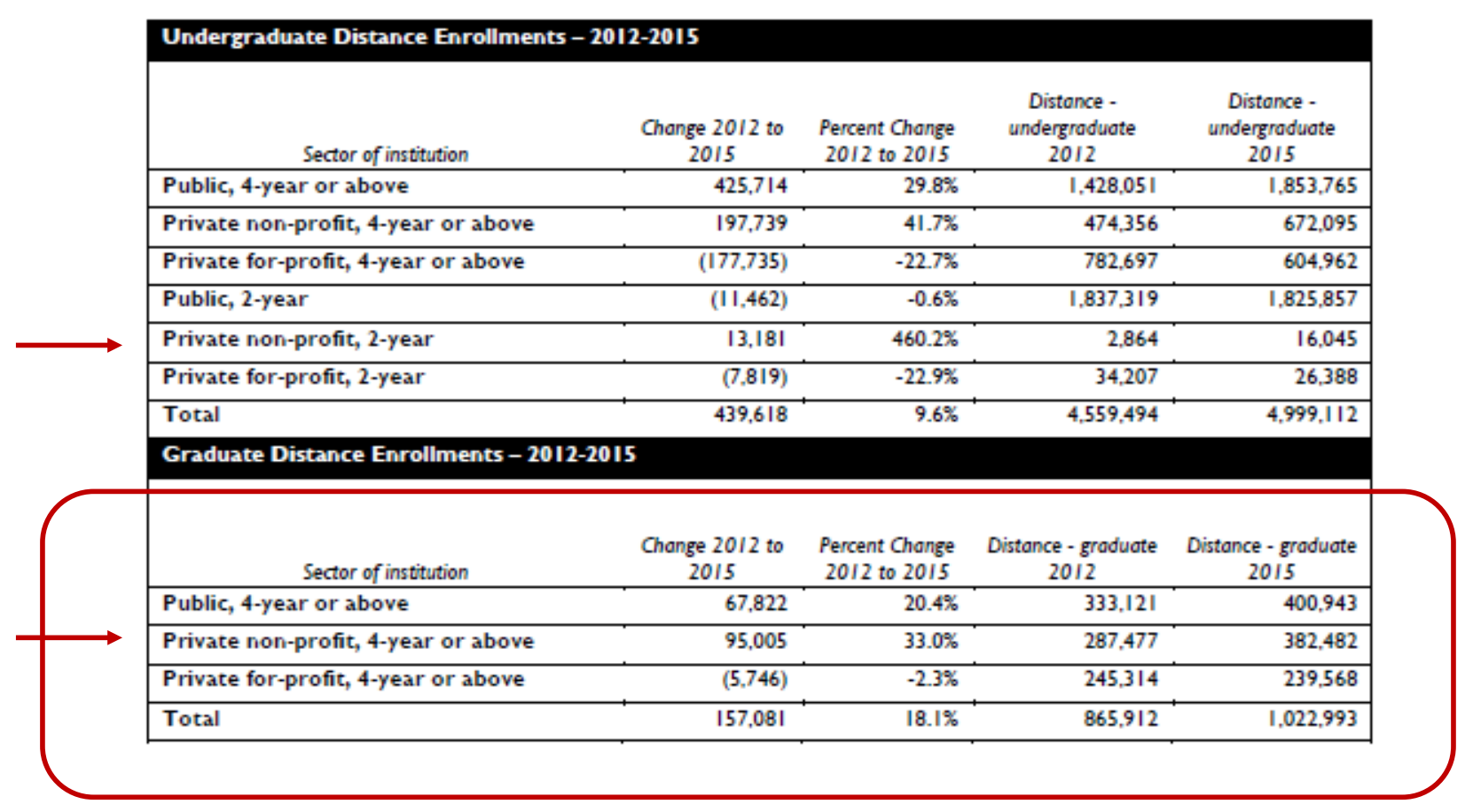

Figure 20 - Distance Enrollment Differences by Institutional Sector [14]

\section{Conclusion}

While attending the Conference for Industry \& Education Collaboration (CIEC) in 2017 at Jacksonville, Florida, a Special Interest Group (SIG) on administration pondered the greatest challenges and concerns for those many individuals and their universities/colleges participating. Although there were many topics discussed, the one recurring topic of greatest interest, the one keeping most awake at night, was the topic of university specific dwindling enrollments in professional graduate programs.

The findings of this paper suggest graduate student enrollment in tuition-based on-campus programs is indeed down from previously increasing year-to-year historical accounts. This, while distance education enrollments are up.

When looking at why tuition-based on-campus enrollments for entering freshmen are down, the literature identifies numerous contributing factors, including:

․ Changing population demographics.

The dwindling number of high school graduates - which, from the research, is premised on declining birth rates, contributed to by higher levels of educational attainment, career pursuits, and increasing greater graduation debt loads.

In reviewing the distance-based enrollment increases, the literature reflected: 
- There is an overall increase in distance education enrollments.

口 Distance enrollments are different by university type, sector within each type and regions.

The one question left unanswered is "why are distance enrollments higher in some institutions and stagnate or lower in others?” To this, the literature suggests distance enrollments are higher in those institutions that place an emphasis on distance programs as more than simply a peripheral venture. Distance enrollments appear to be higher in those institutions that recognize distance education as a predominate source of revenue and a main stay in this particular market niche. In the final analysis, while an area for future research, the differentiator is one of necessity; i.e., is distance education the primary service to those in need of this medium of education?

While not explicitly stated in the literature, from an online fee-based administrative organization subjective perspective, it appears, on the surface, those institutions that have their crossuniversity collective resources dedicated to a centralized online presence, have a greater opportunity to:

C Create university-wide consistent quality offerings.

a Provide a common distance education labor base under a matrix organizational design model.

a Provide career continuity and professional growth; where each person has a functional discipline home.

口 Perpetuate common and consistent technology.

口 Apply a common knowledge on an equal basis.

- Reduce personnel and functional redundancies indicative to decentralization, and, attendant costs.

\section{References}

[1] Allen, I., Seaman, J (2017). Digital Learning Compass: Distance Education Enrollment Report 2017. Babson Survey Research Group.

[2] Moody's (2013). US Higher Education Outlook Negative in 2013. Industry Outlook, January 16, 2013. Downloaded from the internet on July 19, 2013. http://www.marquette.edu/budget/documents/USHigherEducationOutlookNegativein2013.pdf

[3] Marcus, J. (2013). Like Private Businesses, Universities Consolidate to Cut Costs. Downloaded from the internet on July 21, 2013. The Hechinger Report. http://nation.time.com/2013/07/19/cash-strapped-universitiesturn-to-corporate-style-consolidation/?xid=newsletter-daily

[4] Arias, E. (2006). United States life tables, 2003. National Vital Statistics Reports, vol. 54, no. 14. Hyattsville, Md.: National Center for Health Statistics.

[5] Hankin, H. (2005). The New Workforce. New York: AMACOM.

[6] Kotlikoff, L. J. (2004). The Coming Generational Storm. Cambridge, Mass.: MIT Press 
[7] Kinsella, K., and V. Velkoff. (2001). An Aging World: 2001, U.S. Census Bureau, Series P95/01-1. Washington, D.C.: U.S. Government Printing Office.

[8] Saunders, N. (2005). “A Summary of BLS Projections to 2014.” Monthly Labor Review, November. 5.

[9] Wallace, P. (1999). Agequake. London: Nicholas Brealey Publishing.

[10] Herman, R., T. Olivo, and J. Gioia. (2003). Impending Crisis: Too Many Jobs, Too Few People. Winchester, Va.: Oakhill Press.

[11] Dent, H. (2014). The Demographic Cliff. New York, NY.: Penguin Group.

[12] Last, J. (2013). What to Expect When No One's Expecting. New York, NY: Encounter Books

[13] Selingo, J. (2016). 2026 the Decade Ahead - The Seismic Shifts Transforming the Future of Higher Education.

The Chronicle of Higher Education, Inc.

[14] Bransberger, P., Michealu, D. (2016). Knocking at the College Door - Projections of High School Graduates. Western Interstate Commission for Higher Education, Updated July 2017.

[15] Springer, M. L., \& Schuver, M. T. (2015). The New Professional Working Adult Learner - The Next Generational Cohort. ASEE 2015 Annual Conference Proceedings. Seattle, WA.

[16] Springer, M. L. (2016). Project and program management: A competency-based approach. $3^{\text {rd }}$ ed. West Lafayette, IN: Purdue University Press.

[17] Carnevale, A., Smith, N. \& Strohl, J. (2013). Recovery: Job Growth and Educational Requirements through 2020. Georgetown University, Georgetown Public Policy Institute, Center on Education and the Workforce.

[18] Taylor, P. (2010). The New Demography of American Motherhood. PEW Research Center. Downloaded from file:///U:/Personal/Downloads/754-new-demography-of-motherhood.pdf. 